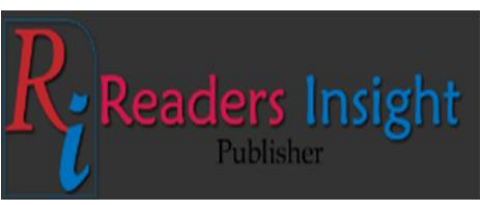

Pak-Euro Journal of Medical and Life Sciences

ISSN: 2707-4471 (Print), 2707-448X (Online)

www.readersinsight.net/pjm/s

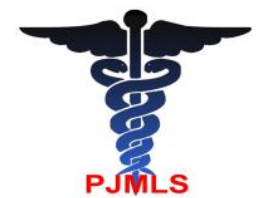

Research Article

\title{
Physicochemical Characteristics and Fatty Acid Profile of Date Palm Phoenix Dactylifera (L) of District Kech, Balochistan, Pakistan.
}

\author{
Sumbila Razzaq ${ }^{*}$, Fazila Razzaq ${ }^{2}$, Adeela Anwar ${ }^{3}$ and Irfan Hafeez ${ }^{4}$
}

${ }^{1}$ Department of Biochemistry, University of Balochistan, Quetta, Pakistan.

${ }^{2}$ Center of Advanced Studies in Vaccinology and Biotechnology (CASVAB), University of Balochistan, Quetta, Pakistan.

${ }^{3}$ Department of biochemistry, Sardar Bahadur khan Women University, Quetta, Pakistan.

${ }^{4}$ Pakistan Council of Scientific and Industrial Research (PCSIR) Lahore Pakistan.

*Corresponding email: sumbila razzaq@yahoo.com

\section{Abstract}

The present study was designed to estimate the physicochemical \& fatty acid profile of date palm Phoenix dactylifera L. grown at kech District, Balochistan. The obtained oil was $9.77 \%$ by the Soxhlet extraction. The fat content in date seed was $9.15 \%$, protein $5.33 \%$, crude fiber $6.89 \%$, ash $1.13 \%$, moisture $9.78 \%$, total carbohydrate content was $73.32 \%$ and refractive index was $1.449 \%$. The chemical properties such as Acid value, Saponification value, lodine value and peroxide value were $1.89 \%, 187.83 \%, 56.568 \%$ and 1.244 respectively. While the mineral analysis was done by using atomic absorption spectrophotometer. The results indicate that potassium was the most abundant mineral $(247.32 \%)$ followed by the magnesium $(63.73 \%)$, phosphorus $(43.07 \%)$ and calcium was $(38.89 \%)$. The fatty acid composition of date seed oil showed that it was oleic-lauric acid being the abundant fatty acid found in it, along with the linoleic, stearic and palmitic acid. The results showed that date seed oil is an excellent nutritional source and it would also play a vital role in cosmetics and nutraceutical industries.

Keywords: Date seeds, ash, fat, acid value, minerals and fatty acids.

\section{ARTICLE INFORMATION}

Received: 08.11.2019

Revised: 18.12 .2019

Accepted: 30.12 .2019

DOI: $10.31580 /$ pjmls.v2i4.1176

\section{INTRODUCTION}

The Phoenix dactylifera Belongs to Aceraceae family having 200 genera and more than 3000 species. It is considered as the oldest fruit tree cultivated by man in hot regions of the world. Its origin of cultivation is unknown, but it is found that it has been originated in some places of Arab countries, North Africa, and some regions of south west Asia (1).

Date palm is a tall tree having male and female plants growing on a separate tree. The female flower possesses a yellowish green color whereas male flowers are white in color. They generally increase their number of generations by sexual and asexual reproduction. It has been observed that a date palm in a vigorous state produces thirty-five to forty branches in its life, and these branches, if in a vigorous state, promote the production of date fruit annually which goes up to hundred kilos. Several other ways are also adopted for their reproduction to get better yield (1).

Dates have power over other fruits religiously as its name is quoted several times in holy book of Muslims as well as its (date palm) importance is also acknowledged in other religions. Muslims widely use dates in the month of Ramadan as it is recommended by the Holy Prophet Muhammad Peace be upon him and that he generally used it for breaking his fast (2).

Date palm fruit has a length of about $2.80 \mathrm{~cm}$ to $5.92 \mathrm{~cm}$ and their diameter also vary in different cultivates. Different colors are also observed in the stages of maturity such as yellow, orange, red (3). Date seeds are habitually considered as a waste product it is mainly used by animals for their feeding.

The Date palm Phoenix (dactylifera L.) has a high nutritional value as it is rich in carbohydrates, proteins, vitamins lipids, fibers and minerals. The presence of all these nutrients makes dates an idyllic food. It is estimated that date palm contain seventy-eighty percent carbohydrates, moreover, it is also a good source of sugar (60 to $65 \%)$, fiber $(2.5 \%)$, protein $(2 \%)$, fat $(0.2-0.5 \%)$, vitamins pectin, and minerals (less than $2 \%$ ) (2) besides all these nutrients dates also possess certain physicochemical and phytochemical constituents which play role in fighting several diseases.

Generally, most of the seed oils are vital and regular food ingredients. They contain saturated fatty acids or unsaturated carboxylic acids with a long aliphatic tail and number of carbon atoms. They possess nutritional values.

Climatic variance and other factors influence the production and consumption of dates in different countries of the world. Pakistan also lies in the list of date producing countries and particularly Kech a district of Balochistan considered as a centre of date palm production. $51 \%$ of the dates produced in Pakistan come from the Kech district. Therefore, the objectives of the study were to determine the physicochemical properties and fatty acid profile of date palm Oil of Kech district of Balochistan which may give a lead to use the date palm oil in industries as well as its application in different diseases. 


\section{METHODOLOGY OF THE STUDY}

\section{Chemical and reagents}

All the chemicals and reagents which were needed for the experimental procedures were purchased from sigma and Merck Company of Pakistan.

\section{Sample collection}

Date palm (phoenix dactylifera L.) were collected from the local market of Kech district, after collection of the sample seeds were removed from the date palm and placed in a separate place, later those seeds were washed to remove all the impurity content from it. Seeds were dried up to make a fine powder by the help of grinder machine in the laboratory of institute of biochemistry. The fine powder of date seeds will be kept in the jar for the oil extraction and further analysis.

\section{Oil extraction of date seeds}

The extraction of date seed oil was done by using the method described by. (4) extraction was carried out by Soxhlet apparatus Weight, about $40 \mathrm{~g}$ seed powder was put in a thimble and added $150 \mathrm{ml} \mathrm{n}$-hexane in the flask, then added some pieces of marble in the flask, the solvent started boiling and moved from the flask to the condenser; the Soxhlet extraction was continued for about six hours per day. The process had been repeated until the extraction completed. By the help of rotary evaporator, the excess solvent evaporated and consequently, the considerable quantity of oil had been obtained. The obtained oil was to be kept in dark brown bottle at $4 \mathrm{C}$ till further analysis. The oil yielded was calculated by the following expression:

Yield of oil extraction $=$ weight of oil extract $/$ Weight of date seeds $\times 100$

\section{Physicochemical parameters}

The physical properties of date seeds such as shape, weight length, and width were determined by the help of digital electrical balance and vernier caliper their values were recorded and mean was calculated.

\section{Ash Content}

Ash content was determined by the method described by (17) date seed powder was heated in muffle furnace for 6 hours at $600 \mathrm{C}$. It was repeated thrice and note their mean by the following expression.

$$
\% \text { Ash content }=\mathrm{W} 1-\mathrm{W} 2
$$

$\mathrm{W} 1=$ weight of the silica crucible + sample before heating.

W2 = weight of the sample + silica crucible after heating.

\section{Moisture Content}

Moisture content was determined by the method described by (19) $2 \mathrm{gm}$ of date seed powder and was ignited in an oven for about 2 hours at $105 \mathrm{C}$. The experiment was done in thrice and mean was calculated.

$$
\% \text { Moisture }=\mathrm{a}-\mathrm{b}
$$

$\mathrm{a}=$ weight of the dish +sample before placed in an oven.

$\mathrm{b}=$ Weight of the dish + sample after drying in an oven

\section{Fiber content}

Fiber content was determined by (25) Digest the sample with Sulphuric acid and then sodium hydroxide. The \% age of crude fiber was calculated by the loss of mass compared to the original mass sample.

\section{Fat Content}

For the determination of fat content method No. 963.15 (AOAC, 2002s) was used with slight modifications. $3 \mathrm{~g}$ of sample was extracted with $n$-hexane by using soxhlet apparatus.

$\%$ crude fat $=$ weight of the fat $\times 100$ Weight of the sample

\section{Total Carbohydrate Content}

The total carbohydrate content was calculated by taking all the sum of moisture, fat, protein, fiber and ash content and subtract it from 100.

$\%$ carbohydrates $=100-(\%$ moisture $+\%$ ash $+\%$ fat $+\%$ protein $+\%$ fiber).

\section{Refractive Index}

The refractive index of seed oil of dates was measured by the help of digital abbey refractometer at the temperature $40 \mathrm{C}$. The experiment was done in triplicate and their mean was calculated and noted as refractive index.

\section{Acid Value}

Acid value was determined by the method described by the British Standards Institution (BS EN ISO 660:2009).

\section{Peroxide Value}

The peroxide value of date seed oil was determined by method described by AOAC official methods and practices of the AOCS (20).

\section{Saponification Value}

Saponification value was determined according to an American standard method (D 5558-95).

\section{lodine Value}

The iodine value was determined according to the method described by AOAC official methods and practices of the AOCS (20).

\section{Protein Content}

The nitrogen value was determined by Kjeldahl method (AOAC 2000). The value of total nitrogen was multiplied by a factor 6.25 .

\section{Fatty Acid Profile}

Fatty acid determination was done according to the method described by (18) with slight modifications.

\section{Preparation of fatty acid methyl esters (FAMEs)}

An oil sample of $1 \mathrm{~g}$ was poured into the test tube then added $0.2 \mathrm{ml}$ internal standard and $0.5 \mathrm{~N}$ methanolic $\mathrm{NaOH}$ (sodium hydroxide) $15 \mathrm{ml}$. After settling the test tube, it was placed in the water bath, the temperature of water bath was set at $80 \mathrm{C}$ for thirty-minutes. then another test tube was taken, and $4 \mathrm{ml}$ above mentioned solution was added, and $5 \mathrm{ml}$ of BF3 (Boron-trifluoride) in methanol was added. The test tube was heated in the same manner as had been done previously. After 
heating, the solution had been cooled down at room temperature. After that, $5 \mathrm{ml}$ of saturated $\mathrm{NaCl}$ (sodium chloride) solution was added and it was centrifuged. The process had been repeated out thrice with $2 \mathrm{ml}$ of hexane. A little amount of anhydrous sodium sulphate was added to the hexane extract in order to remove the water content.

\section{Determination of fatty acid methyl esters ( FAMEs)}

After preparation of fatty acid methyl esters, for their analysis, the oven temperature was adjusted. Firstly, it was set at $84 \mathrm{C}$ for four minutes after that the temperature raised to $175 \mathrm{C}$ at a rate $15 \mathrm{C} /$ minute for 15 minutes $220 \mathrm{C}$ at a rate of $25 \mathrm{C}$ /mint for 25 minutes and $240 \mathrm{C}$ at a rate of $4 \mathrm{C} / \mathrm{mint}$ for 10 minutes. The temperature of injector was set at $220 \mathrm{C}$ and for injector at $240 \mathrm{C}$. The temperature for column was $140 \mathrm{C}$ and the gas which was used as carrier was nitrogen, had a flow rate of $40 \mathrm{~m} / \mathrm{mint}$.

The standard and peaks of fatty acid methyl esters (FAMEs) were obtained by injecting 0.1-0.2uL hexane solution into GC fitted with FID (flame ionization detector). Identified with the help of their retention time to compare with standards.

\section{Statistical analysis}

The average and standard deviation were calculated with Microsoft excel 2009 all analysis was carried out in triplicate and the results were expressed as mean \pm standard deviation.

\section{RESULTS AND DISCUSSION}

The physical parameters of date palm (Phoenix dactylifera $\mathrm{L})$ are shown in Table 1. The length of date seeds were 2.76 whereas the diameter was 1.36 these results were compared with the results of Hamada et al., 2002 (6). He reported the physical dimensions of date seed varieties grown south east Morocco. According to another research, the values were 2.75 and 1.15 respectively (26) was also shown the range of length and diameter of date seeds in between 14.11-23.22 mm and 6.85-9.02 $\mathrm{mm}$. The variation lies just because of the different land, cultivars and environmental factors.

Table 1. Physical dimensions of date palm seeds

\begin{tabular}{cc}
\multicolumn{2}{c}{ (Phoenix dactylifera L) } \\
\hline Physical dimensions & \pm SDM \\
\hline Length $(\mathrm{cm})$ & $2.76 \pm 0.030$ \\
& $1.36 \pm 0.15$ \\
Diameter $(\mathrm{cm})$ & golden yellow \\
Seed oil color & rhombus and ellipsoid \\
Shape &
\end{tabular}

All values were taken in triplicate of mean \pm standard deviation ( \pm SDM).

Table 2. Proximate analysis of date palm seed oil of (Phoenix dactylifera $\mathrm{L}$ )

\begin{tabular}{cc}
\hline Physical Properties (\%) & \pm SDM \\
\hline Ash content & $1.13 \pm 0.045$ \\
Moisture content & $9.78 \pm 0.111$ \\
Refractive index & $1.449 \pm 0.007$ \\
Crude fiber & $6.89 \pm 1.13$ \\
Fat & $9.15 \pm 0.04$ \\
Carbohydrate & $73.32 \pm 0.61$ \\
Protein content & $5.33 \pm 0.2516$ \\
\hline
\end{tabular}

All values were taken in triplicate of mean \pm standard deviation.

Table 3. Physicochemical properties of date palm seed oil (Phoenix dactylifera L.)

\begin{tabular}{c|c}
\hline $\begin{array}{c}\text { Physiochemical } \\
\text { Properties }\end{array}$ & \pm SDM \\
\hline $\begin{array}{c}\text { Oil yield \% } \\
\text { Acid value } \\
\text { (mg KOH g oil) }\end{array}$ & $9.77 \pm 0.517$ \\
$\begin{array}{c}\text { Saponification value } \\
\text { (mg KOH g oil) }\end{array}$ & $187.83 \pm 0.121$ \\
$\quad \begin{array}{l}\text { lodine value } \\
\text { (g of l/100g oil) }\end{array}$ & $56.568 \pm 1.8516$ \\
$\quad \begin{array}{c}\text { Per-oxide value } \\
\text { (mEq/kg oil) }\end{array}$ & $1.244 \pm 0.068$ \\
\hline w
\end{tabular}

All values were taken in triplicate of mean \pm standard deviation.

Table 4. Mineral analysis of date palm seed oil (Phoenix dactylifera L.)

\begin{tabular}{cc}
\hline Minerals & Amount Present \\
\hline Potassium $(\mathrm{K})$ & $247.32(\mathrm{mg} / 100 \mathrm{~g}$ oil) \\
Magnesium $(\mathrm{Mg})$ & $63.73(\mathrm{mg} / 100 \mathrm{~g}$ oil) \\
Calcium $(\mathrm{Ca})$ & $38.89(\mathrm{mg} / 100 \mathrm{~g}$ oil) \\
Phosphorus $(\mathrm{P})$ & $43.07(\mathrm{mg} / 100 \mathrm{~g}$ oil) \\
\hline
\end{tabular}

Table 5. Fatty acid profile of date palm seed oil

\begin{tabular}{cc}
\multicolumn{2}{c}{ (\% of total fatty acid) } \\
\hline Fatty Acids & Percentage Present \\
\hline Oleic acid ( C 18:1) & $49.72 \%$ \\
Lauric acid (C12:0) & $13.73 \%$ \\
Linoleic acid (C18:2) & $20.23 \%$ \\
Stearic acid (C18:0) & $8.97 \%$ \\
Palmatic acid (C16:0) & $7.35 \%$ \\
\hline
\end{tabular}

The proximate analysis results such as ash, moisture, crude fiber, fat, refractive index protein content has been shown in the Table 2. The ash content is defined as the grey inorganic residue left after the burning of a sample the ash value of date seed obtained was $1.17 \%$ which were lower than the values reported by Besbes et al., 2004 (7) and greater than the values reported by Abdalla et al., 2012 (8).

Moisture content in the date seeds of phoenix dactylifera $\mathrm{L}$. obtained was $9.78 \%$ which was compared to the results reported by Choe \& Min 2006 (10). The obtained values of crude fiber and fat were 6.89 and 9.15 . The result of crude fiber was in agreement to the results reported by Habib \& Ibrahim 2009 (23). The fat value of date seeds 9.15 was accepted according to the standards defined by Association of Official Analytical Chemists in 1995 (24), Whereas, the refractive index was 1.449 which were compared by Herch et al., 2014 (9).

The amount of carbohydrate and protein found in date palm was 73.32 and 5.33 , which was compared with the results reported by Besbes et al., 2004 (7) and Zang et al., 2017 (16). The carbohydrates indicate the presence of high energy found in the date palms which was ultimately rapid source of energy consumed by humans in their diet as date palm contain less fat and high carbohydrate which proves that the people took dates in their diet on regular basis they were save from cardinal diseases. 


\section{Oil Yield \& Physicochemical Characteristics}

The physicochemical results were shown in the Table 3. The oil yield from seeds of date palm Phoenix dactylifera $L$. was $9.77 \%$. It was light golden in color and semisolid at room temperature. Acid value generally represents the small amount of free fatty acid in the oil the resulted AV $(1.8949 \mathrm{mgKOH} / \mathrm{g})$ was very low which showed that oil contained less number of free fatty acid which represents the stability of oil and it shows that the oil is edible and safe for consumption. The value was compared to the results reported by Hamada et al., 2002 (6) seed varieties of date palm Moroccan Sahara.

Saponification value (SV) shows the nature and length of the fatty acid chain it depends on the fatty acids average molecular weight. The high saponification value showed that date seed oil contained large number of carbon atoms and normal triglyceride content which were very productive in manufacturing of soap and shampoos. The resultant SV was $187.83 \mathrm{mg} \mathrm{KOH} / \mathrm{g}$ which was very close to the results compared by Choe \& Min 2006 (10).

lodine value is the unsaturation degree of fats and oils. It represents the absorption of iodine number per $100 \mathrm{gm}$ sample. The IV was 56.568 and it was less than 100 which indicates that date seed oil is a non drying oil (21). Our result have high iodine value which are similar to the findings reported by Hamada et al., 2002 (6) of Majhoul seed variety, whereas it was lower than the Bousthammi and Boufgous date palm seed variety.

Peroxide value of date seed oil was $1.244 \mathrm{mEq} / \mathrm{kg}$ which shows that it was less vulnerable to autoxidation. These variations can arise from variant factors such as the degree of unsaturation of the fatty acids present in the particular oil, exposure to light, storage, and the content of metals or other compounds that may catalyze the oxidation process (11). The low peroxide value can considered safe for human consumption and possess a long storage of the oil (12). The resultant value of peroxide was in agreement to the result reported by Hamada et al., 2002 (6).

\section{Mineral Analysis of Date Seed Oil}

The minerals found in the date seed oil was assembled in the Table 4. Potassium (247.32) was found in the excessive amount followed by the magnesium (63.73) phosphorus (43.07) also constituents but it was less than potassium and magnesium while the calcium (38.89) was found in the least amount followed by the other four elements. These minerals play a vital role in human growth and development. The obtained results were compared with the findings of Abdalla et al., 2012 (8), who reported the mineral contents of two Tunisian cultivars (Deglet Nour and Allig). The slight difference exhibited because of the variations in variety of date palm as well as the environmental factors, different soil and fertilizers.

\section{Fatty Acid Profile of Date Seed Oil}

The fatty acid results are illustrated in Table 5. The oleic acid was found in excess as $49.72 \%$ followed by linoleic acid which constitute about $20.23 \%$, whereas lauric, stearic and palmitic acid were $13.73,8.97$ and $7.35 \%$ respectively. Among the five fatty acids, four were monounsaturated while the remaining one i.e. linoleic acid was polyunsaturated. In general, the oils which possess the high content of oleic acid showed good flavor and better stability of frying. As well as it is considered good for human health. Linoleic acid plays role in the skin nourishment. Due to the unsaturation of these fatty acids they prevent from several diseases. Hence it played a significant role in the medicinal field. The present results were accepted by $(13,14,22,15)$ which were in range of palmitic $(0.42-15.09)$, stearic $(1.66-605)$, oleic $(32.16-55.10)$, linoleic (4.33-21.00) and lauric acid (0.11-38.81).

\section{CONCLUSION}

Generally most of the seed oils are vital and regular food ingredients and the present study on date palm phoenix dactylifera also showed the good results of physicochemical characters, presence of minerals and fatty acid composition proved that it could be used as a vital by product to meet the sufficient caloric requirement as well as in the cosmetics product for the healthy skin and also used in the production of herbal medicines.

\section{REFERENCES}

1. El Hadrami A, Daayf F, El Hadrami I. Date palm genetics and breeding In Date Palm Biotechnology 2011 (pp. 479-512). Springer, Dordrecht.

2. Al-Farsi M, Alasalvar C, Morris A, Baron M, Shahidi F. Comparison of antioxidant activity, anthocyanins, carotenoids, and phenolics of three native fresh and sun-dried date (Phoenix dactylifera L.) varieties grown in Oman. Journal of agricultural and food chemisstry. 2005 Sep 21;53(19):7592-9.

3. Baloch AK, Baloch WA, Baloch MK, Saleem SA. Shelf stability of Dhakki dates as influenced by water activity and headspace atmosphere. InIII International Date Palm Conference 7362006 Feb 19 (pp. 575-586)

4. Ali MA, Al-Hattab TA, Al-Hydary IA. Extraction of date palm seed oil (Phoenix dactylifera) by Soxhlet apparatus. International Journal of Advances in Engineering \& Technology. 2015 Jun 1;8(3):261.

5. Bouhlali ET, Alem C, Ennassir J, Benlyas M, Mbark AN, Zegzouti YF. Phytochemical compositions and antioxidant capacity of three date (Phoenix dactylifera L.) seeds varieties grown in the South East Morocco. J Saudi Soc Agric Sci. 2015;16:350-357.

6. Hamada JS, Hashim IB, Sharif FA. Preliminary analysis and potential uses of date pits in foods. Food chemistry. 2002;76(2):135-7.

7. Besbes S, Blecker C, Deroanne C, Lognay G, Drira NE, Attia $H$. Quality characteristics and oxidative stability of date seed oil during storage. Food science and technology international. 2004;10(5):333-8.

8. Abdalla RS, Albasheer AA, El-Hussein AR, Gadkariem EA. Physico-chemical characteristics of date seed oil grown in Sudan. American Journal of Applied Sciences. 2012;9(7):9939.

9. Herch W, Kallel H, Boukhchina S. Physicochemical properties and antioxidant activity of Tunisian date palm (Phoenix dactylifera L.) oil as affected by different extraction methods. Food Science and Technology. 2014;34(3):464-70

10. Choe E, Min DB. Mechanisms and factors for edible oil oxidation. Comprehensive reviews in food science and food safety. 2006;5(4):169-86.

11. Gotoh N, Wada S. The importance of peroxide value in assessing food quality and food safety. JAOCS, 
Journal of the American Oil Chemists' Society. 2006;83(5):473.

12. Sameera S, Ken N, Said A.The Emerging Australian Date Palm Industry: Date Fruit Nutritional and Bioactive Compounds and Valuable Processing By-Products. Comprehensive Reviews in Food Science and Food Safety. 2015;14:813-823.

13. Fayadh JM, Al-Showiman SS. Chemical composition of date palm (Phoenix dactylifera L.). J. Chem. Soc. Pak. 1990;12(1):84-103.

14. Habib HM, Kamal H, Ibrahim WH, Al Dhaheri AS. Carotenoids, fat soluble vitamins and fatty acid profiles of 18 varieties of date seed oil. Industrial Crops and Products. 2013;42(1):567-72.

15. Sawaya WN, Khalil JK, Safi WJ. Chemical composition and nutritional quality of date seeds. Journal of Food Science. $1984 ; 49(2): 617-9$.

16. Zang CU, Jock AA, Garba IH, Chindo IY. Physicochemical and Phytochemical Characterization of Seed Kernel oil From Desert Date (Balanites Aegyptiaca). J. Chem. Eng. Bioanal. Chem. 2017;2:49-61.

17. Horwitz W. Assosication of official method analytical chemist. 18 edition Washington DC USA. AOAC 2006.

18. Arlington, Official method of analysis of the Association of Official Analyticatical Chemist. International (USA), No. 93406. AOAC 1990.

19. AOAC Official methods and practices of the AOCS. 5TH edition AOCS Press, Champaign, USA (1998).

20. Asuquo, J.E. Studies of the adsorption of selected metallic soaps onto hematite. Phd. Dissertation, University of port Harcourt, Nigeria (2008).

21. Nehdi I, Omri S, Khalil MI, Al-Resayes SI. Characteristics and chemical composition of date palm (Phoenix canariensis) seeds and seed oil. Industrial crops and products. 2010;32(3):360-5.

22. Salomón-Torres R, Ortiz-Uribe N, Sol-Uribe JA, VillaAngulo C, Villa-Angulo R, Valdez-Salas B, García-González C, Iniguez Monroy CG, Norzagaray-Plasencia S. Influence of different sources of pollen on the chemical composition of date (Phoenix dactylifera L.) cultivar Medjool in México. Aust. J. Crop. Sci. 2018;12(6):1008-1015.

23. Habib HM, Ibrahim WH. Nutritional quality evaluation of eighteen date pit varieties. International Journal of Food Sciences and Nutrition. 2009;60(sup1):99-111.

24. Official Method of Analysis (16th Ed.). AOAC,1995. Association of Official Analytical Chemists.

25. Juhaimi FA, Ghafoor K, Özcan MM. Physical and chemical properties, antioxidant activity, total phenol and mineral profile of seeds of seven different date fruit (Phoenix dactylifera L.) varieties. International journal of food sciences and nutrition. 2012;63(1):84-9.

26. Zaid A, De Wet PF. Chapter I botanical and systematic description of date palm. (http://www.fao.org/3/Y4360E/y4360e05.htm). 